\section{Jurnal Mitra Pendidikan (JMP Online)}

URL : http://e-jurnalmitrapendidikan.com

\title{
MENINGKATKAN KINERJA KEPALA SEKOLAH DALAM MENGELOLA KEUANGAN SEKOLAH DI SDI BAOPUKANG KECAMATAN NAGAWUTUNG
}

\author{
Paulus Kia \\ SDI Baopukang Kecamatan Nagawutung
}

INFORMASI ARTIKEL

Dikirim : 03 Juli 2020

Revisi pertama : 08 Juli 2020

Diterima : 15 Juli 2020

Tersedia online : 31 Juli 2020

Kata Kunci: Kinerja Kepala Sekolah, Mengelola Keuangan

Email:paulus07@gmail.com
ABSTRAK

Tujuan dari penelitian ini adalah untuk mengetahui kinerja kepala sekolah dalam pengelolaan keuangan sekolah melalui bendahara di SDI Baopukang Kecamatan Nagawutung.

Hasil pembahasan adalah pada pelaksanaan siklus I, hasil yang dicapai adalah telah cukup baik yaitu kepala sekolah mengamati secara langsung cara kerja bendahara dalam mengelola keuangan sekolah dan tidak ditemukan kejanggalan hanya beberapa kelemahan seperti kurang lengkapnya bukti kuitansi dan nota lainnya yang disebabkan karena tercecer dan kelebihan yang dicapai pada pelaksanaan siklus II adalah dalam memeriksa laporan keuangan bendahara melaksanakan dengan baik. Dengan demikian tidak dilanjutkan pada penelitian ke siklus III.

Pelaksanaan penelitian tentang meningkatnya kinerja kepala sekolah dalam mengelola keuangan sekolah dapat disimpulkan bahwa dalam mengelola keuangan sekolah dibutuhkan bendahara yang jujur dan bertanggungjawab dan dapat mengetahui penggunaan dana sesuai dengan kebutuhan yang diperlukan. 


\section{PENDAHULUAN \\ Latar Belakang}

Sesuai dengan Pasal 46 Ayat (1) UU No. 20 Tahun 2003, pendanaan pendidikan menjadi tanggung-jawab bersama antara Pemerintah, Pemerintah Daerah dan masyarakat. Berkaitan dengan itu sekolah diharapkan mampu, mengelola sumberdaya yang dimilikinya, untuk merancang berbagai program yang akan ditawarkan kepada masyarakat, menetapkan prioritas, dan membina / meningkatkan kerjasama dengan berbagai sumber dana yang potensial. Dengan diterbitkannya UU No. 20 Tahun 2003, sekolah (negeri) mempunyai keleluasaan untuk memperoleh dana dari berbagai sumber lain di luar APBN / APBD, yaitu antara lain lewat iuran pendidikan, penerimaan siswa baru (PSB), hibah perorangan, dan lain-lain. Tentu saja keleluasaan yang diamanatkan oleh undangundang harus tetap memperhatikan kepada aturan main yang digariskan dalam UU, PP, dan Kepmen yang berlaku. Keleluasaan memperoleh dana masyarakat dipengaruhi oleh banyak faktor antara lain favorit tidaknya suatu sekolah (akreditas). Bagi sekolah di kota, masyarakat / wali murid tidak segan-segan memberikan sumbangan yang terkait dengan pendidikan anaknya, sebaliknya bagi sekolah pinggiran atau di pelosok yang biasa-biasa saja dana masyarakat sulit diharapkan. Dampak yang dirasakan dari perbedaan ini pada akhirnya menyangkut kualitas siswa dan alumninya. Sekolah favorit maju dengan pesat sedangkan sekolah pinggiran sulit untuk mengejar ketinggalan (semakin keterbelakangan). Oleh karena itu, akan dibahas pengelolaan keuangan sekolah, sehingga penggunaan dana pendidikan dapat berjalan secara efektif dan efisien.

Pengelolaan keuangan sekolah dari masing-masing sekolah tentunya berbeda-beda. Begitu halnya dengan SDI Baopukang. Di sekolah ini yang mengatur keuangan sekolah adalah bendahara mengetahui kepala sekolah. Dalam mengelola keuangan sekolah, bendahara membuat laporan keuangan kepada kepala sekolah setiap bulan namun ada kendala yang dihadapi sehingga harus diatasi. Dengan demikian kepala sekolah akan mengadakan penelitian di SDI Baopukang dengan mengambil judul "Meningkatkan Kinerja Kepala Sekolah dalam Mengelola Keuangan Sekolah di SDI Baopukang Kecamatan Nagawutung”.

\section{Rumusan Masalah}

Rumusan masalah dalam penelitian ini adalah bagaimana meningkatkan kinerja kepala sekolah dalam mengelola keuangan sekolah di SDI Baopukang Kecamatan Nagawutung?.

\section{Tujuan Penelitian}

Berdasarkan rumusan masalah diatas, maka tujuan dalam penelitian ini adalah untuk mengetahui kinerja kepala sekolah dalam mengelola keuangan sekolah di SDI Baopukang Kecamatan Nagawutung.

\section{Manfaat Penelitian}

Manfaat dalam penelitian ini adalah untuk memenuhi kebutuhan sekolah baik bagi guru, siswa maupun pegawai sehingga dapat meningkatkan prestasi belajar. 


\section{KAJIAN PUSTAKA \\ Pengertian dan Faktor yang Mempengaruhi Kinerja}

Kinerja berasal dari kata job performance atau actual performance yang berarti prestasi kerja atau prestasi sesungguhnya yang dicapai oleh seseorang. Pengertian kinerja (prestasi kerja) adalah hasil kerja secara kualitas dan kuantitas yang dicapai oleh seorang pegawai dalam melaksanakan fungsinya sesuai dengan tanggung jawab yang diberikan kepadanya. Performance atau kinerja merupakan hasil atau keluaran dari suatu proses (Nurlaila, 2010:71). Menurut pendekatan perilaku dalam manajemen, kinerja adalah kuantitas atau kualitas sesuatu yang dihasilkan atau jasa yang diberikan oleh seseorang yang melakukan pekerjaan (Luthans, 2015:165). Kinerja merupakan prestasi kerja, yaitu perbandingan antara hasil kerja dengan standar yang ditetapkan (Dessler, Gary, 2015:41). Kinerja adalah hasil kerja baik secara kualitas maupun kuantitas yang dicapai oleh seseorang dalam melaksanakan tugas sesuai tanggung jawab yang diberikan (Mangkunagara, 2013:22).

Kinerja adalah hasil atau tingkat keberhasilan seseorang secara keseluruhan selama periode tertentu dalam melaksanakan tugas dibandingkan dengan berbagai kemungkinan, seperti standar hasil kerja, target atau sasaran atau kriteria yang telah ditentukan terlebih dahulu telah disepakati bersama (Rivai dan Basri, 2014:50). Sedangkan Mathis dan Jackson (2016:65) menyatakan bahwa kinerja pada dasarnya adalah apa yang dilakukan atau tidak dilakukan pegawai. Manajemen kinerja adalah keseluruhan kegiatan yang dilakukan untuk meningkatkan kinerja perusahaan atau organisasi, termasuk kinerja masing-masing individu dan kelompok kerja di perusahaan tersebut. Kinerja merupakan hasil kerja dari tingkah laku (Amstrong, 2010:15). Pengertian kinerja ini mengaitkan antara hasil kerja dengan tingkah laku. Sebgai tingkah laku, kinerja merupakan aktivitas manusia yang diarahkan pada pelaksanaan tugas organisasi yang dibebankan kepadanya.

\section{Faktor-Faktor yang Mempengaruhi Kinerja}

1. Efektifitas dan efisiensi

Bila suatu tujuan tertentu akhirnya bisa dicapai, kita boleh mengatakan bahwa kegiatan tersebut efektif tetapi apabila akibat-akibat yang tidak dicari kegiatan menilai yang penting dari hasil yang dicapai sehingga mengakibatkan kepuasan walaupun efektif dinamakan tidak efesien. Sebaliknya, bila akibat yang dicari-cari tidak penting atau remeh maka kegiatan tersebut efesien (Prawirosentono, 2011:27).

2. Otoritas (wewenang)

Otoritas menurut adalah sifat dari suatu komunikasi atau perintah dalam suatu organisasi formal yang dimiliki seorang anggota organisasi kepada anggota yang lain untuk melakukan suatu kegiatan kerja sesuai dengan kontribusinya (Prawirosentono, 2011:27). Perintah tersebut mengatakan apa yang boleh dilakukan dan yang tidak boleh dalam organisasi tersebut.

3. Disiplin

Disiplin adalah taat kepda hukum dan peraturan yang berlaku (Prawirosentono, 2011:27). Jadi, disiplin karyawan adalah kegiatan karyawan 
yang bersangkutan dalam menghormati perjanjian kerja dengan organisasi dimana dia bekerja.

4. Inisiatif

Inisiatif yaitu berkaitan dengan daya pikir dan kreatifitas dalam membentuk ide untuk merencanakan sesuatu yang berkaitan dengan tujuan organisasi.

\section{Pengertian Pengelolaan Keuangan}

Pengertian Pengelolaan keuangan pendidikan merupakan salah satu substansi pengelolaan sekolah yang turut menentukan berjalannya kegiatan pendidikan di sekolah. Menurut Depdiknas (2014) bahwa pengelolaan keuangan merupakan tindakan pengurusan dan ketatausahaan keuangan yang meliputi pencatatan, perencanaan, pelaksanaan, pertanggung jawaban dan pelaporan. Sedangkan, Menurut Jones (2012), pengelolaan keuangan meliputi :

1. Perencanaan financial, yaitu kegiatan mengkoordinir semua sumber daya yang tersedia untuk mencapai sasaran yang diinginkan secara sistematik tanpa efek samping yang merugikan.

2. Pelaksanaan (implementation involves accounting), yaitu kegiatan berdasarkan rencana yang telah dibuat.

3. Evaluasi, yaitu proses penilaian terhadap pencapaian tujuan. Dengan demikian, pengelolaan keuangan sekolah merupakan proses perencanaan, penggalian sumber, penyusunan anggaran dan penggunaan serta pelaporan keuangan di tingkat sekolah. Adapun beberapa kegiatan pengelolaan keuangan yaitu memperoleh dan menetapkan sumber-sumber pendanaan, pemanfaatan dana, pelaporan, pemeriksaan dan pertanggung jawaban (Afirin, Zainal. 2012).

\section{Prinsip-Prinsip Pengelolaan Keuangan Sekolah}

Pengelolaan keuangan sekolah perlu memperhatikan sejumlah prinsip. Menurut undang-undang No.20 Tahun 2003 pasal 48 ayat (1) menyatakan bahwa pengelolaan dana pendidikan berdasarkan pada prinsip keadilan, efisiensi, transparansi dan akuntabilitas publik. Berikut akan dibahas masing-masing prinsip tersebut, yaitu transparansi, akuntabilitas, efektivitas, dan efisiensi :

1. Transparansi Transparan berarti adanya keterbukaan. Di lembaga pendidikan, bidang pengelolaan keuangan yang transparan berarti adanya keterbukaan dalam pengelolaan keuangan lembaga pendidikan, yaitu keterbukaan sumber keuangan dan jumlahnya, rincian penggunaan, dan pertanggung jawabannya harus jelas sehingga bisa memudahkan pihak-pihak yang berkepentingan untuk mengetahuinya. Transparansi keuangan dapat menciptakan kepercayaan timbal balik antara pemerintah, masyarakat, orang tua siswa dan warga sekolah, sehingga dapat meningkatkan dukungan orangtua, masyarakat dan pemerintah dalam penyelenggaraan seluruh program pendidikan di sekolah. Salah satu informasi keuangan yang bebas diketahui oleh semua warga sekolah dan orang tua siswa misalnya rencana anggaran pendapatan dan belanja sekolah (RAPBS). RAPBS ini bisa ditempel di papan pengumuman di ruang guru atau di depan ruang tata usaha sehingga siapa saja yang membutuhkan informasi itu dapat dengan mudah melihatnya. Orang tua siswa bisa mengetahui berapa jumlah 
uang yang diterima sekolah dari orang tua siswa dan digunakan untuk apa saja uang itu. Perolehan informasi ini dapat menambah kepercayaan warga sekolah dan orang tua siswa terhadap sekolah.

2. Akuntabilitas Akuntabilitas adalah kualitas performansi seseorang dalam menyelesaikan tugas untuk mencapai tujuan yang menjadi tanggung jawabnya. Jadi, akuntabilitas di dalam pengelolaan keuangan berarti penggunaan uang sekolah dapat dipertanggung jawabkan sesuai dengan perencanaan yang telah ditetapkan dan peraturan yang berlaku. Pertanggung jawaban dapat dilakukan kepada orang tua, masyarakat dan pemerintah. Ada tiga pilar utama yang menjadi prasyarat terciptanya akuntabilitas, yaitu :

a. Adanya transparansi para penyelenggara sekolah dengan menerima masukan dan mengikut sertakan berbagai komponen dalam mengelola sekolah.

b. Adanya standar kinerja di setiap institusi yang dapat diukur dalam melaksanakan tugas, fungsi dan wewenangnya.

c. Adanya partisipasi untuk saling menciptakan suasana kondusif dalam menciptakan pelayanan masyarakat dengan prosedur yang mudah, biaya yang murah dan pelayanan yang cepat.

3. Efektivitas Efektif umumnya yaitu pencapaian tujuan yang telah ditetapkan. Garner (2004) mendefinisikan efektivitas tidak berhenti sampai pencapaian tujuan saja tetapi sampai pada kualitatif hasil yang dikaitkan dengan pencapaian visi lembaga. Effectiveness "characterized by qualitative outcomes". Efektivitas lebih menekankan pada kualitatif outcomes. Pengelolaan keuangan dikatakan memenuhi prinsip efektivitas jika kegiatan yang dilakukan dapat mengatur keuangan untuk membiayai aktivitas dalam rangka mencapai tujuan lembaga yang bersangkutan dan kualitatif outcomes-nya sesuai dengan rencana yang telah ditetapkan.

4. Efisiensi Efisiensi berkaitan dengan kuantitas hasil suatu kegiatan. Efficiency "characterized by quantitative outputs" (Garner, 2004). Efisiensi adalah perbandingan yang terbaik antara masukan (input) dan keluaran (output) atau antara daya dan hasil. Daya yang dimaksud meliputi tenaga, pikiran, waktu dan biaya. Perbandingan tersebut dapat dilihat dari dua hal :

Dilihat dari segi penggunaan waktu, tenaga dan biaya Kegiatan dapat dikatakan efisien jika penggunaan waktu, tenaga dan biaya yang sekecil-kecilnya dapat mencapai hasil yang ditetapkan.

Dilihat dari segi hasil Kegiatan dapat dikatakan efisien jika dengan penggunaan waktu, tenaga dan biaya tertentu memberikan hasil sebanyakbanyaknya baik kuantitas maupun kualitasnya. Tingkat efisiensi dan efektivitas yang tinggi memungkinkan terselenggaranya pelayanan terhadap masyarakat secara memuaskan dengan menggunakan sumber daya yang tersedia secara optimal dan bertanggung jawab.

\section{Tugas Pengelola Keuangan Sekolah}

Dalam pelaksanaannya, pengelolaan keuangan menganut asas pemisahan tugas antara fungsi Otorisator, Ordonator, dan Bendaharawan. Otorisator adalah pejabat yang diberi wewenang untuk mengambil tindakan yang mengakibatkan 
penerimaan dan pengeluaran anggaran. Ordonator adalah pejabat yang berwenang melakukan pengujian dan memerintahkan pembayaran atas segala tindakan yang dilakukan berdasarkan otorisasi yang telah ditetapkan. Bendaharawan adalah pejabat yang berwenang melakukan penerimaan, penyimpanan, dan pengeluaran uang serta diwajibkan membuat perhitungan dan pertanggung jawaban. Kepala Sekolah, sebagai pengelola, berfungsi sebagai Otorisator dan di limpahi fungsi Ordonator untuk memerintahkan pembayaran. Namun, tidak dibenarkan melaksanakan fungsi Bendaharawan karena berkewajiban melakukan pengawasan ke dalam. Sedangkan Bendaharawan, disamping mempunyai fungsi Bendaharawan, juga di limpahi fungsi ordonator untuk menguji hak atas pembayaran. Pengelola keuangan sekolah berkewajiban untuk menentukan keuangan sekolah, cara mendapatkan dana untuk infrastruktur sekolah serta penggunaan dana tersebut untuk membiayai kebutuhan sekolah. Tugas pengelola keuangan antara lain :

1. Pengelolaan untuk perencanaan perkiraan.

2. Pengelolaan memusatkan perhatian pada keputusan investasi dan pembiayaannya.

3. Pengelolaan kerjasama dengan pihak lain.

4. Penggunaan keuangan dan mencari sumber dananya. Seorang pengelola keuangan harus mempunyai pikiran yang kreatif dan dinamis.

Hal ini penting karena pengelolaan yang dilakukan oleh seorang pengelola keuangan berhubungan dengan masalah keuangan yang sangat penting dalam penyelenggaraan kegiatan sekolah. Adapun yang harus dimiliki oleh seorang pengelola keuangan yaitu strategi keuangan.

Strategi itu antara lain :

1. Strategic Planning Keterkaitan antara tekanan internal dan kebutuhan ekternal yang datang dari luar. Terkandung unsur analisis kebutuhan, proyeksi, peramalan, ekonomic dan financial.

2. Strategic Management Upaya mengelolah proses perubahan, seperti: perencanaan, strategis, struktur organisasi, kontrol, strategis dan kebutuhan primer.

3. Strategic Thinking Sebagai kerangka dasar untuk merumuskan tujuan dan hasil secara berkesinambungan.

\section{Penggunaan Keuangan Sekolah}

Dana yang diperoleh dari berbagai sumber dibukukan dan diagendakan untuk menunjang kegiatan pembelajaran di kelas, laboratorium, perpustakaan, serta di tempat lainnya digunakan secara efektif dan efisien, dan sasaran penggunanaan dana tersebut sesuai rencana dan program yang diperkirakan akan mencapai target dan tujuan pembelajaran sekaligus tujuan sekolah. Pemerintah telah menyusun suatu kategori dalam bentuk mata anggaran, kategori ini dimaksudkan agar sasaran penggunaan anggaran dapat tersusun sedemikian rupa dan diukur tingkat pencapaian tiap-tiap komponen. 
Adapun komponen yang baku dan yang berlaku disekolah menurut buku T.5 (Depdikbud, 2014:84) adalah :

1. Program Rutin

a. Gaji dan tunjangan

b. Tunjangan beras

c. Lembur

d. Keperluan alat kantor

e. Barang Inventaris

f. Langganan daya/jasa (Listrik, telepon, air)

g. Kegiatan belajar mengajar

h. Pemeliharaan Gedung

2. Program pembangunan

a. D.P.P = Dana Pembinaan Pendidikan

b. D.B.O = Dana Bantuan Operasi

c. = Oprasi Pembangunan dan fasilitas

Berdasarkan SKB Mendikbud dan Menkeu No. 585/k/1987 dan 590/kmk 03/03/1987 tanggal 24 september 1987 kegiatan-kegiatan tersebut adalah antara lain :

a. Pemeliharaan saran/prasanara

b. $\mathrm{PBM} / \mathrm{KBM}$

c. Pembinaan Kegiatan Siswa

d. Dukungan Kegiatan Personil

e. Kegiatan R.T Sekolah/Komite Sekolah

\section{Pengawasan dan Evaluasi Anggaran}

Yang dimaksud dengan pengawasan anggaran adalah suatu pemeriksaan yang terutama ditujukan pada masalah keuangan (transaksi, dokumen, buku, daftar serta laporan), antara lain untuk memperoleh kepastian bahwa berbagai transaksi keuangan dilakukan sesuai dengan undang-undang, peraturan, keputusan, instruksi untuk menilai kewajaran yang diberikan oleh laporan keuangan. Kaidah atau ukuran yang ditetapkan oleh pihak yang berwenang dalam rangka melaksanakan fungsi pengawasan sebagaimana diatur dalam Instruksi Presiden No 15 tahun 1983 meliputi pengawasan fungsional dan pengawasan melekat yang berpedoman kepada norma sebagai berikut :

a. Pengawasan tidak mencari-cari kesalahan, yaitu tidak mengutamakan mencari siapa yang salah, tetapi apabila ditemukan kesalahan, penyimpangan dan hambatan supaya dilaporkan sebab-sebab dan bagaimana terjadinya, serta menemukan bagaimana memperbaikinya.

b. Pengawasan merupakan proses yang berlanjut yaitu dilaksanakn terus menerus, sehingga dapat memperoleh hasil pengawasan yang berkesinambungan,

c. Pengawasan harus menjamin adanya kemungkinan pengambilan koreksi yang cepat dan tepat terhadap penyimpangan dan penyelewengan yang ditemukan untuk mencegah berlanjutnya kesalahan dan atau penyelewengan,

d. Pengawasan bersifat mendidik dan dinamis, yaitu dapat menimbulkan kegairahan untuk memperbaiki, mengurangi atau meniadakan penyimpangan di 
samping menjadi pendorong dan perangsang untuk menertibkan penyempurnaan kondisi obyektif pengawasan.

Pelaporan dan Pertanggung Jawaban Penerimaan dan pengeluaran keuangan sekolah harus dilaporkan dan dipertanggungjawabkan secara rutin sesuai peraturan yang berlaku. Pelaporan dan pertanggungjawaban anggaran yang berasal dari orang tua siswa dan masyarakat dilakukan secara rinci dan transparan sesuai dengan sumber dananya. Pelaporan dan pertanggungjawaban anggaran yang berasal dari usaha mandiri sekolah dilakukan secara rinci dan transparan kepada dewan guru dan staf sekolah. Beberapa prinsip yang dijadikan pegangan dalam kegiatan mempertanggungjawabkan keuangan yang dilakukan oleh atasan langsung, meliputi :

a. Diusahakan secara singkat dan dilaksanakan pada setiap akhir pecan.

b. Periksa terlebih dahulu Buku Kas Umum dalam hubungannya dengan buku yang lain setiap akhir bulan.

c. Diperingatkan kepada bendaharawan mengenai: pengiriman SPJ (Surat Pertanggung Jawaban) bulanan, penyetoran MPO/PPn.

d. Diperiksa pengurusan barang inventaris dan penyimpanan dokumen pertanggal keuangan sewaktu-waktu.

e. Diadakan pemeriksaan kas dengan menyusun Berita Acara Pemeriksaan Kas setiap akhir triwulan secara teratur.

f. Atasan langsung bendaharawan bertanggung jawab atas kerugian keuangan Negara.

g. Dilaporkan dengan segera (paling lambat satu minggu) jika terjadi kerugian yang diderita oleh Negara karena penggelapan atau perbuatan lain, kepada Sekretaris Jenderal Depdiknas c.q. Kepala Biro Keuangan dengan tembusan kepada Inspektur Jenderal Depdiknas dan BPK.

\section{Alokasi Pengelolaan Keuangan Sekolah}

Pendanaan pendidikan saat ini dapat dikelompokkan menjadi biaya personalia dan operasi nonpersonalia. Biaya personalia, terdiri dari gaji pendidik dan tenaga kependidikan serta tunjangan-tunjangan yang melekat pada gaji dan biaya nonpersonalia adalah biaya untuk bahan atau peralatan pendidikan habis pakai dan biaya tak langsung berupa daya, air, jasa telekomunikasi, pemeliharaan sarana dan prasarana, uang lembur, transportasi, konsumsi, pajak, asuransi, dan lain-lain (baca Permendiknas nomor 69 tahun 2009, tentang Standar Biaya Operasi Nonpersonalia Tahun 2009 Untuk Sekolah Dasar/Madrasah Ibtidaiyah (SD/MI), Sekolah Menengah Pertama/Madrasah Tsanawiyah (SMP/MTs), Sekolah Menengah Atas/Madrasah Aliyah (SMA/MA), Sekolah Menengah Kejuruan (SMK), Sekolah Dasar Luar Biasa (SDLB), Sekolah Menengah Pertama Luar Biasa (SMPLB), dan Sekolah Menengah Atas Luar Biasa (SMALB). Biaya operasi nonpersonalia adalah standar biaya yang diperlukan untuk membiayai kegiatan operasi nonpersonalia selama 1 (satu) tahun sebagai bagian dari keseluruhan dana pendidikan agar satuan pendidikan dapat melakukan kegiatan pendidikan secara teratur dan berkelanjutan sesuai SNP. Apabila dirinci anggaran sekolah tersebut digunakan untuk : 
a. Kegiatan peningkatan mutu pendidikan, antara lain peningkatan kemampuan profesional, supervisi pendidikan, dan evaluasi.

b. Kegiatan ekstra-kurikuler, antara lain usaha kesehatan sekolah (UKS), pramuka, olahraga, kreativitas seni.

c. Bahan pengajaran praktek, keterampilan, antara lain penambahan sarana pengajaran, bahan praktek.

d. Kesejahteraan Kepala Sekolah, guru dan pegawai.

e. Pembelian peralatan kantor dan alat tulis kantor.

f. Pengembangan perpustakaan.

g. Pembangunan sarana fisik sekolah.

h. Biaya listrik, telepon, air dan surat menyurat.

i. Dana sosial seperti bantuan kesehatan, pakaian seragam.

j. Biaya pemeliharaan gedung, pagar dan pekarangan sekolah

Pengeluaran anggaran tersebut dilaksanakan dengan memperhatikan jenis mata anggaran keluaran (MAK) sebagai berikut :

1. Belanja Pegawai

a. Belanja Gaji Pegawai

b. Belanja Honorarium Pegawai

2. Belanja Barang

a. Keperluan Sehari-Hari Perkantoran

b. Belanja Barang ATK

c. Langganan Daya dan Jasa

d. Pemeliharaan Gedung Kantor

e. Pemeliharaan Peralatan dan Mesin

f. Biaya Perjalanan Dinas

3. Belanja Modal

a. Belanja Modal Peralatan dan Mesin

b. Belanja Modal Gedung dan Bangunan

4. Belanja Sosial Belanja bantuan sosial, berupa Penyediaan Beasiswa dan peningkatan Sumber Daya Manusia Dalam rangka peningkatan mutu pendidikan di sekolah, perlu pengelolaan sumber daya terpadu antara sumber daya manusia, sarana dan prasarana serta dana. Ketiganya saling terkait satu sama lain. Dalam hal ini kepala sekolah dituntut untuk mengatur keuangan sekolah dengan tidak sebaik- baiknya sehingga ada kegiatan yang semestinya mendapat prioritas pendanaan tapi tidak memperoleh anggaran.

\section{METODE PENELITIAN}

\section{Jenis, Lokasi dan Subyek Penelitian}

Jenis penelitian adalah penelitian tindakan sekolah (PTS). Lokasi penelitian di SDI Baopukang dan subyek penelitian adalah bendahara sekolah. Penelitian dilaksanakan pada bulan Agustus hingga September 2019. 


\section{Prosedur Penelitian} berikut :

Adapun langkah-langkah dalam penelitian tindakan sekolah adalah sebagai

1. Perencanaan

Langkah-langkah yang dilakukan dalam perencanaan sebagai berikut :

a. Mengadakan pengamatan awal untuk mengidentifikasi permasalahan yang perlu segera diatasi. Peneliti melakukan wawancara terhadap bendahara sekolah.

b. Menyiapkan jadwal kegiatan penelitian.

c. Membuat instrumen pengamatan bagi bendahara untuk mengetahui cara kerjanya.

d. Membuat pedoman wawancara bagi bendahara tentang kesulitan-kesulitan dalam membuat laporan keuangan.

2. Pelaksanaan tindakan

Pelaksanaan siklusnya adalah sebagai berikut :

a. Pada siklus I, kepala sekolah sebagai peneliti melakukan pengamatan dan wawancara langsung untuk mengambil data.

b. Pada siklus 2, membahas kegiatan selama penelitian dalam bentuk laporan hasil penelitian.

3. Observasi dan evaluasi

Observasi dan evaluasi setelah tindakan dilakukan untuk mengumpulkan data yaitu dalam laporan pertanggungjawaban keuangan oleh bendahara.

4. Refleksi

Peneliti menganalisis semua informasi yang dalam proses laporan keuangan dan pembelajaran mulai dari mencatat hasil observasi, mengevaluasi hasil observasi dan memperbaiki kelemahan untuk menyusun tindakan yang akan dilakukan pada siklus 2 .

\section{Teknik Pengumpulan Data}

Data diperoleh dari hasil pengamatan, wawancara dan catatan lapangan untuk penilaian proses :

a. Hasil pengamatan

Pengamatan dilakukan oleh peneliti pada saat proses setelah tindakan dilakukan, hasil pengamatan terekam dalam format pengamatan. Rekap hasil pengamatan terhadap laporan keuangan.

b. Wawancara

Wawancara dilakukan oleh peneliti setelah tindakan dilakukan. Wawancara dilakukan untuk mengetahui kemampuan bendahara dalam menguasai penatausahaan keuangan sekolah serta kesulitan-kesulitannya.

\section{Teknis Analisis Data}

Data yang dianalisis adalah data dari hasil observasi, wawancara dan cacatan lapangan yang diperoleh sebelum dan selama berlangsungnnya penelitian tindakan sekolah. 
Teknik analisis data yang digunakan adalah secara kualitatif, yaitu dengan menghitung besarnya prosesntase dari masing-masing indikator penelitian. Pengumpulan data yang dilakukan melalui pengamatan, wawancara, catatan lapangan, dianalisis sejak proses berlangsung penelitian, sehingga hal ini menunjukan bahwa penelitian tindakan sekolah prosesnya bersamaan pada saat pengumpulan data.

Diharapkan data dari hasil penelitian ini dapat menggambarkan mengenai keuangan sekolah di SDI Baopukang. Hal ini akan tampak dari hasil perhitungan prosentasenya dari kegiatan di siklus 1 yang dibandingkan dengan hasil di siklus 2.

\section{HASIL PENELITIAN DAN PEMBAHASAN Hasil Penelitian Siklus I}

Siklus I dilaksanakan pada minggu pertama dan minggu kedua bulan Agustus 2019. Pada minggu pertama, kepala sekolah mewawancarai bendahara dengan menyampaikan maksud dan tujuan diadakan penelitian. Setelah bendahara menyetujui maka kegiatan awal yang dilakukan kepala sekolah adalah melakukan pengamatan langsung aktifitas bendahara dalam mengelola keuangan sekolah sesuai dengan fungsi dan Rencana Kegiatan Anggaran Sekolah (RKS) dalam bulan Agustus.

Pengamatan ini dilakukan kepala sekolah selama pelaksanaan siklus I. Kepala sekolah meminta bendahara mencatat semua alokasi dana pendidikan dengan fungsinya masing- masing dan memberi waktu selama satu minggu. Pada minggu kedua, bendahara memberi hasil rekapan dana yang masuk ke sekolah. Rekapan ini dapat dilihat pada data dibawah ini :

a. Dana partisipasi / tahun Rp.120.000,-

b. Dana BOS / tahun Rp. 126.000.000,- (Pencairan / 3 bulan)

c. Dana pembangunan / KK Rp. 100.000,- / tahun

d. Dana lain- lain (Cendramata, uang pagar)

Hasil rekapan diatas belum lengkap menurut kepala sekolah, sehingga kepala sekolah meminta bendahara untuk membuat rincian yang lengkap secara garis besarnya saja. Kepala sekolah meminta bendahara untuk memberi laporan ulang yang belum lengkap seperti dana BOS yang akan dialokasikan ke pos mana saja. Hal ini terjadi pada minggu ketiga dan keempat. Hasil rekapan dana BOS dialokasikan untuk :

a. Belanja pegawai untuk bayar guru honor dan operator sekolah sebesar $15 \%$

b. Belanja barang dan jasa sebesar $16 \%$

c. Belanja modal sebesar $25 \%$

Sedangkan sarana dan prasarana yang rusak diambil dari belanja modal dan dana lain seperti uang pagar, uang cendramata dipercayakan kepada masingmasing guru kelas. Untuk uang cendramata dikumpulkan dan dipegang oleh salah satu guru. Pelaksanaan siklus I menurut pengamatan kepala sekolah dan observer cukup baik selama bulan Agustus, tetapi masih ada kelemahan yang dialami bendahara seperti : 
a. Kekurangan pembuatan kuitansi dan nota yang lainnya tercecer

b. Belum beresnya laporan keuangan pada bulan sebelumnya.

Melihat hasil pelaksanaan siklus I yang mengalami banyak kekurangan, maka kepala sekolah memberi motivasi kepada bendahara untuk merekap kembali semua laporan keuangan sesuai dengan fungsi dan berpedoman pada Rencana Kegiatan Anggaran Sekolah (RKS).

\section{Siklus II}

Pelaksanaan siklus II dilaksanakan pada minggu pertama dan minggu kedua bulan September 2019. Dalam pelaksanaan siklus II kepala sekolah dibantu oleh observer untuk mengamati kegiatan yang dilakukan bendahara. Pada siklus II yang berlangsung selama dua minggu ini hasil pengamatan cukup baik. Bendahara SDI Baopukang adalah Bapak Klemens Kejara, S.Pd. Beliau adalah seorang guru selaku bendahara yang dipercaya kepala sekolah untuk mengatur keuangan sekolah. Selama pelaksanaan siklus II kepala sekolah menyruh bendahara untuk merekap semua laporan keuangan selama tahun 2019 yaitu dari bulan Januari sampai bulan September. Selama menjabat sebagai bendahara, tidak ditemukan hal- hal yang menyimpang tentang keuangan sekolah. Pada siklus II ini kepala sekolah mengadakan pemeriksaan dan mendapat nilai yang positip bagi bendahara karena mengelolanya dengan baik dan buku laporan keuangannya lengkap. Kepala sekolah mengadakan pemeriksaan setiap bulan untuk mengetahui penggunaan keuangan di sekolah tersebut. Kelemahan terjadi yang ditemukan kepala sekolah dalam laporan keuangan oleh bendahara telah diperbaiki seperti kuitansi dan notanota belanja telah disusun dengan baik sebagai bukti. Pelaksanaan siklus II ini berjalan dengan baik dan kepala sekolah sebagai peneliti puas dan tidak melakukan penelitian ke siklus III.

\section{Observasi dan Evaluasi}

Observasi atau pengamatan yang dilakukan pada siklus I dan II oleh observer dan kepala sekolah terhadap aktifitas yang dijalankan bendahara selama bulan Agustus dan September, baik siklus I maupun siklus II mendapat nilai baik, tidak ditemukan hal-hal yang menyimpang. Hanya beberapa kesulitan yang dialami bendahara yaitu seperti sudah dijelaskan pada siklus I, kuitansi dan notanota belanja tercecer dan tidak diatur secara baik, tetapi setelah dilakukan pemeriksaan oleh kepala sekolah maka hal tersebut bisa diatasi dengan baik. Hasil laporan keuangan akan dilaporkan ke kepala sekolah setiap bulan dan kepala sekolah akan mempertanggungjawabkan penggunaan keuangan sekolah ke Dinas PKO dalam bentuk laporan keuangan. Pendampingan ini dilakukan setiap semester. Untuk diketahui dalam penelitian ini kepala sekolah tidak melampirkan data hasil laporan keuangan selama bulan Januari sampai Agustus karena peneliti hanya menjelaskan dan melaporkan secara deskriptifnya saja yaitu kegiatan bendahara dalam mengelola keuangan sekolah dan tidak mengambil data kuatitatifnya. 


\section{Refleksi}

Setelah merenung kembali pelaksanaan kegiatan penelitian siklus I dan siklus II, ternyata ada kelemahan dan keuntungan yang dicatat kepala sekolah sebagai bahan renungan yaitu :

a. Pelaksanaan siklus I mengalami kendala yaitu bendahara dalam membuat laporan keuangan tidak melampirkan kuitansi atau nota

b. Belum beresnya laporan keuangan pada bulan sebelumnya

Sedangkan keuntungan yang diperoleh adalah :

c. Pelaksanaan siklus I dan siklus II dapat berjalan dengan baik

d. Tidak ditemukan penyimpangan yang dilakukan bendahara

e. Dapat mengetahui kegiatan yang dilakukan bendahara setiap hari

Dengan melihat hasil dari renungan ini maka menjadi bahan refleksi bagi kepala sekolah dalam mengelola keuangan sekolah adalah pengelolaan keuangan yang baik dapat meningkatkan kinerja kepala.

\section{KESIMPULAN DAN SARAN \\ Kesimpulan}

Pelaksanaan siklus I dan siklus II dalam penelitian tentang meningkatkan kinerja kepala sekolah dalam mengelola keuangan sekolah dapat disimpulkan sebagai berikut :

a. Dalam mengelola keuangan sekolah dibutuhkan bendahara yang jujur dan bertanggungjawab

b. Pemeriksaan laporan keuangan harus dilakukan secara rutin

c. Penggunaan dana sesuai dengan kebutuhan yang diperlukan

d. Dapat mengetahui kelemahan dan kekurangan yang dialami bendahara

e. Dapat mengetahui kekurangan dan kelebihan sarana dan prasarana yang ada di sekolah

\section{Saran}

Setelah mengadakan penelitian ini dan hasil yang dicapai pada siklus I dan siklus II maka dapat disarankan :

1. Untuk penelitian lanjutan perlu dipaparkan hasil laporan keuangan SDI Baopukang ke publik sebagai bahan kajian informasi.

2. Memberikan motivasi kepada bendahara untuk mengikuti pelatihan tentang penatausahaan keuangan sekolah

\section{DAFTAR PUSTAKA}

A.A. Anwar Prabu Mangkunegara. 2013. Manajemen Sumber Daya Manusia Perusahaan. Bandung: PT. Remaja Rosda Karya

Adisasmita, Rahardjo. 2014. Pengelolaan Pendapatan dan Anggaran Daerah. Yogyakarta: Graha Ilmu.

Afirin, Zainal. 2012. Evaluasi Pembelajaran Prinsip, Teknik, Prosedur. Bandung: PT Remaja Rosdakarya.

Amstrong, Mischael. 2010. Manajemen Sumber Daya Manusia. Terjemahan Sofyan dan Haryanto. PT. Elex Media Komputindo. Jakarta. 
Depdikbud. 2014. PERMENDIKBUD No.58 Th. 2014 tentang Kurikulum 2013

Sekolah Menengah Perrtama/Madrasah Tsanawiyah. [Online]. Tersedia: http://staff.unila.ac.id/ngadimunhd/files/2012/03/Permen-58-ttg-

KurikulumSMP.doc. Diakses dari laman web tanggal 8 Juni 2016.

Depdiknas. 2003. Undang-Undang RI No.20 Tahun 2003 tentang Sistem Pendidikan Nasional

Depdiknas. 2014. Permendikbud No. 146 Tahun 2014. Jakarta: Depdiknas.

Dessler, Gary. 2015. Manajemen Sumber Daya Manusia. Jakarta: Salemba Empat.

James C. Van Horne, dan John M. Wachowicz, Jr. 2012. Prinsip-prinsip Manajemen Keuangan (Fundamentals of Fina).

Luthans, Fred. 2015. Perilaku Organisasi 10th. Edisi Indonesia. Yogyakarta: Penerbit ANDI.

Mathis, R.L. \& J.H. Jackson. 2016. Human Resource Management: Manajemen Sumber Daya Manusia. Terjemahan Dian Angelia. Jakarta: Salemba Empat

Mulyasa. 2014. Pengembangan dan Implementasi Kurikulum 2013. Bandung: Remaja Rosdakarya.

Nurlaila, 2010. Manajemen Sumber Daya Manusia I. Penerbit LepKhair

Prawirosentono, Suryadi. 2011. Kinerja. Bandung: Alfabeta.

Rivai, Veitzhal dan Basri. 2014. Performance Appraisal. Jakarta: Prenada Media.

Robbins, Stephen P dan Timothy A Judge. 2014. Perilaku Organisasi. Jakarta: Salemba Empat.

Utari, Nuraeni. 2009. Studi Fenomenologis Tentang Proses Penyusunan Anggaran Berbasis Kinerja Pada Pemerintah Kabupaten Temanggung. Program Studi Magister Akuntansi. Program Pasca Sarjana Universitas Diponegoro Tahun 2009 